\title{
戸建住宅における冷却塔放射冷房の仕様・運用条件に関する研究 A STUDY ON THE SPEC AND THE OPERATION CONDITION OF THE HOUSING INDOOR CLIMATE CONTROLLING BY THE PANEL COOLING WITH COOLING TOWER
}

\author{
石原衣梨*, 高橋 達**
}

Eri ISHIHARA and Itaru TAKAHASHI

\begin{abstract}
It is vitally important to develop a space cooling system which realize the both of low exergy consumption and thermal comfort in hot and humid area. So the purpose of this paper is to grasp the relationship between the effect of indoor climate controlling and the spec and the operation condition of the housing panel cooling with cooling tower assisted by passive strategies. Followings were found by a numerical analysis at the the AIJ standard model of wooden house. The spec and the operation in the case that the lowest room air temperature is realized is the combination of the cooling panels position on the floor and the ceiling, thermal storage parts in whole walls, the running time of the panel cooling from 11:00 to 14:00 and from 16:00 to 19:00,ventilation time from 16:00 to 8:00 and so on.
\end{abstract}

Keywords: Cooling Tower, Radiative Cooling, Passive Cooling 冷却塔, 放射冷却, パッシブクーリング

\section{1. 研究の背景と目的}

近年、環境負荷低減の一つの方法としてパッシブクーリングが認識 されつつある。特に、2011年は福島第一原子力発電所事故が起こった ため、関東、東北圈内を発端上して全国的に節電が呼びかけられる事 態になった。そのため、冷房用電力の需要が高まる夏期は、エアコン

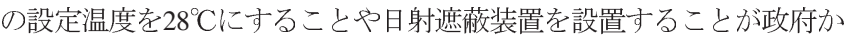
ら推奨されるなど、冷房用電力使用量を削減し、室空気温が高い場合 でも快適に過ごすための手法が全国的に見直された。

筆者らは、日射遮蔽や換気、断熱、蓄熱などのパッシブ手法を徹底 した上で酷暑時には低エクセルギ一利用のアクティブ手法を複合する ことにより、快適性の確保と環境負荷の低減を両立するようなシステ ムの研究を以前から行っており22334)、その社会的実現を試みている5 そのようなシステムの一つに、冷却塔を泠却源とした放射冷房がある。 水を用いた放射冷房は冷却源に冷却塔を用いた放射冷房 (以下、冷却 塔放射冷房)の他に、屋根流水を利用した天井放射冷房 ${ }^{6}$ や井水放射冷 房・外気予泠兼用システム 2 、二重屋根採冷システムがある3 ${ }^{334}$ 。馬・ 須永による屋根流水を利用した天井放射冷房の研究》では、室内グロー ブ温度が $27^{\circ} \mathrm{C}$ 以下で、室内相対湿度が $60 \%$ 以上の場合でも、6割の被 験者が快適と申告することが確認されている。また、深井・岩松・淺 田・宿谷らは、室内相対湿度が $70 \%$ 以上の場合でも、室空気温・周壁
平均温度がともに $29^{\circ} \mathrm{C}$ 以下で風速が $0.15 \mathrm{~m} / \mathrm{s}$ 以上で女れば、快適性が 得られることを確認している ${ }^{81}$ c五十嵐・水澤・高橋らも同様のことを 二重屋根採泠システムの被験者実験で確認している3)。 泠却塔放射冷房は、冷却塔を通過した水の温度が外気温湿度にお惊 る湿球温度以上になるため、放射冷却面温度が露点温度より高くなる ことから、他の放射冷房より結露のリスクを著しく縮小できる。榊原・ 荒谷・石田は冷却塔放射冷房を発案し、数值シミュレーションにより 日射遮蔽や換気の有無に関する検討を行っている ${ }^{9 !}$ 。近年では、 Vangtook・Chirarattananonが数值シミュレーションだけでなく、レンガ 造の実験小屋を対象上した実験を行っているが10)、パッシブ手法上の 複合については検討していない。これらの既往研究では、バッシブ手 法と泠却塔放射冷房の複合システム全体の仕様・運用条件上冷房効果・ 結露の関係に関寸る詳細な検討、スケールなどによる配管防食を防ぐ ための実務的な検討が行われていない。そのため、熱的快適性、結露 回避を実現するための、冷却塔放射冷房の設備仕様・運用条件、建物 熱性能の仕様、運用条件を合わせて把握する必要がある。

以上のことから本研究では、住宅を対象とした冷却塔放射冷房に関 する数值シミュレーションを行うことで、設計に必要な仕様・運用条 件と冷房効果などとの関係を定量的に把握することを目的とする。

\footnotetext{
本論文の一部は既発表論文 1 )を加筆・修正したものである。

* (有) $\mathrm{ZO}$ 設計室

(当時 東海大学大学院 大学院生)

** 東海大学工学部 准教授. 博士 (工学)
}

ZO Consulting Engineers, M. Eng.

(Ex-Graduate Student, Tokai Univ.)

Assoc. Prof., Faculty of Eng., Tokai Univ., Dr. Eng. 


\section{2. 研究方法}

\section{2-1 数值シミュレーションの方法}

図1に冷却塔放射冷房のシステムを示寸。冷却塔放射冷房は、冷却塔 における水の蒸発作用により湿球温度近くまで泠却した雨水や上水 (以 下、冷却水)を、床・天井内の埋設配管に流れる水 (以下、冷水) と熱交 換することで、床や天井を冷却し、放射冷房を行うシステムである。

計算モデルを定めるために、後述する日本建築学会標準問題モデル ${ }^{11)}$ の木造住宅を対象にして、冷却塔放射冷房の設備設計を行った。冷 却塔はメーカーから市販されている最小能力 (最大冷却能力 $2 \mathrm{~kW}$ 、定格 電力 $15 \mathrm{~W}$ 、流量 $26 \mathrm{~L} / \mathrm{min}$ )のものを選定した。上水使用量が 過大にならないようにするため、雨水で上水の一部を代替寸 るようにした。また、放射冷却面は、家具のレイアウトによ る影響が小さく、放射冷却面積を大きくとれる床上天井の2 面上した。なお、放射泠却面には蓄冷効果により室空気温・ 周壁温度の振幅を小さくするために蓄熱部位を設けることが 有用上考えている。冷水循環ポンプは流量 $3 \mathrm{~L} / \mathrm{min}$ 、管径 $20 \mathrm{~mm}$ の配管圧力損失から揚程を算出し、選定した。その結 果、一次側、二次側循環ポンプは上もに定格電力50Wのも のになった。

熱交換槽は市販の雨水貯留タンクとし、熱交換器 $(20 \mathrm{~A} の$ 銅管を直径 $500 \mathrm{~mm}$ で 18 段に巻いたもの注7) が設置できる、 市販品における最小容量 $(W 500 \mathrm{~mm} \times \mathrm{D} 500 \mathrm{~mm} \times \mathrm{H} 930 \mathrm{~mm}$ 、 200L) とした。一般に蓄熱槽と呼ばれる一次側タンクを熱交 換槽と表記したのは、本論文では設置スペースの観点から一

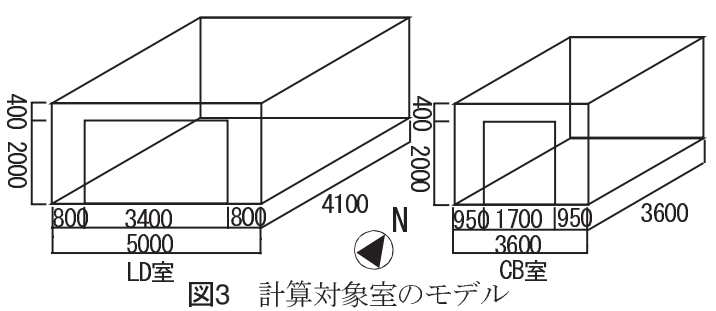

般に導入しや寸い小容量を想定しており、そのことによって蓄熱効率 が低く、蓄熱槽上呼ぶのが妥当ではないためである。本システムでは、 熱交換槽と雨水貯留タンクが必要になるため、雨水貯留タンクは、北 側の敷地境界上外壁との間隔から人の通る幅上タンク2基分のコスト を考慮し、寸法が W $800 \mathrm{~mm} \times \mathrm{D} 800 \mathrm{~mm} \times \mathrm{H} 1250 \mathrm{~mm}$ 、容量が $600 \mathrm{~L}$ の ものを想定した。また、雨水貯留タンクと熱交換槽、冷却塔は日射の 当たらない北側地上に設置すると仮定した。

2-2 数值シミュレーションの条件

図2に計算対象住宅の $1 \mathrm{~F}$ 平面、図3、図4に計算対象室のモデル、躯

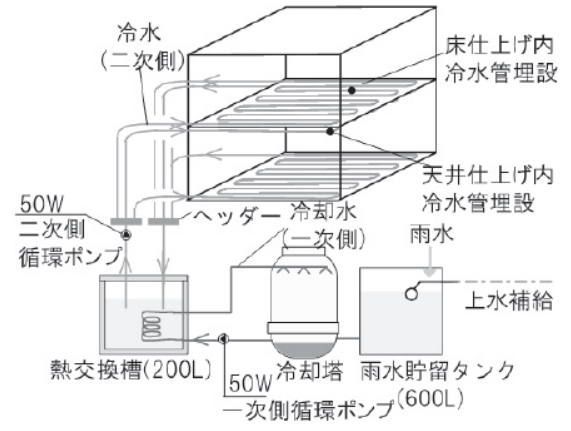

図1冷却塔放射冷房のシステム

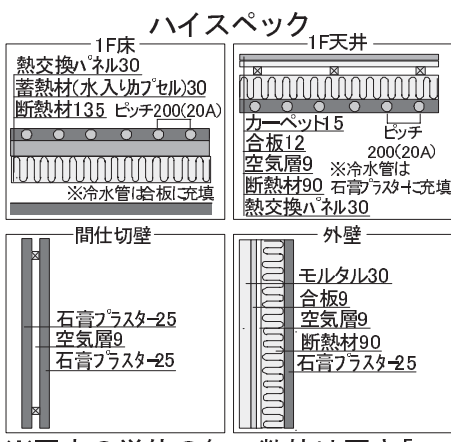

※図中の単位の無い数值は厚さ $[\mathrm{mm}] 。 ※$ 断熱材はグラスウール24K ※冷水管は架橋ポリエチレン管。

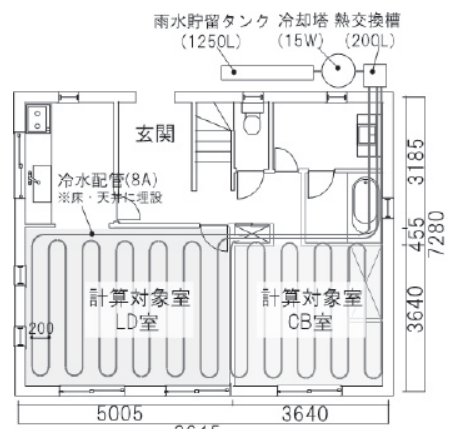

図2 計算対象住宅の $1 \mathrm{~F}$ 平面

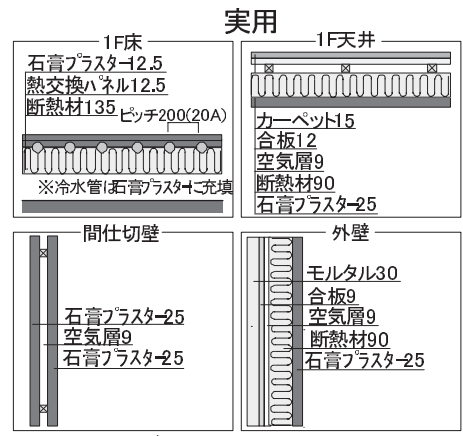

图躯体の断面構成

表1冷却塔放射冷房に関わる計算式

室空気の熱収支
$Q_{r} \frac{\mathrm{d} \theta_{r}}{\mathrm{~d} t}+\sum_{j=1}^{N} S_{j} \alpha_{i c}\left(\theta_{r}-\theta_{j}\right)+G_{v}\left(\theta_{r}-\theta_{a}\right)=H \quad$ (1)

壁体内部質点 $\mathrm{k}$ での熱収支 ${ }^{22}$

$Q_{k} \frac{\mathrm{d} \theta_{k}}{\mathrm{~d} t}+{ }_{+1} C_{k}\left(\theta_{k}-\theta_{k+1}\right)+{ }_{-1} C_{k}\left(\theta_{k}-\theta_{k-1}\right)=0$

\section{壁内表面の熱収支 ${ }^{12}$}

$$
\begin{aligned}
{ }_{-1} C_{k+1}\left(\theta_{k+1}-\theta_{k}\right) & +\alpha_{i c}\left(\theta_{k+1}-\theta_{r}\right) \\
& +\alpha_{i r}\left(\theta_{k+1}-\sum g_{i j} \theta_{k}\right)=R_{i}
\end{aligned}
$$

放射冷却面内部における配管部分の諸変数 ${ }^{13)}$

(4) $\theta_{k}=\left(1-\eta_{F}^{*}\right) \theta_{E}+\eta_{F}^{*} \theta_{k p}$

$$
\ell=(w-d) / 2
$$

$\eta_{F}^{*}=(1-d / w) \eta_{F}+d / w$

(5) $z=\left({ }_{-1} C_{k}+{ }_{+1} C_{k}\right) /(d \cdot \lambda)$

(6) $\eta_{F}=\tanh (\ell \sqrt{z}) /(\ell \sqrt{z})$

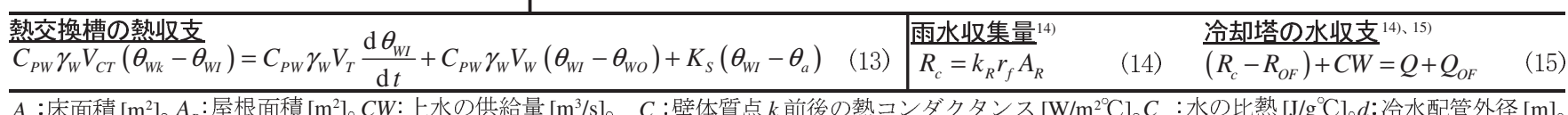

$A_{F}$ : 床面積 $\left[\mathrm{m}^{2}\right]_{\circ} A_{R}$ : 屋根面積 $\left[\mathrm{m}^{2}\right]_{0} C W$ : 上水の供給量 $\left[\mathrm{m}^{3} / \mathrm{s}\right]_{\sigma_{+}} C_{k}$ : 壁体質点 $k$ 前後の熱コンダクタンス $\left[\mathrm{W} / \mathrm{m}^{20} \mathrm{C}\right]_{\circ} C_{p w}:$ 水の比熱 $\left[\mathrm{J} / \mathrm{g}{ }^{\circ} \mathrm{C}\right]_{\circ} d:$ 冷水配管外径 $[\mathrm{m}]_{\circ}$ $E: \theta_{W O}$ を $\theta_{k}$ の一次関数として扱うために必要な係数。 $g_{i j}$ : 面 $i$ 亿対する面 $j$ の放射吸収係数 $[-]_{\circ} G_{v}:$ 隙間換気量の熱容量 $\left[\mathrm{W} /{ }^{\circ} \mathrm{C}\right]_{0} H:$ 内部発熱 $[\mathrm{W}]_{0}$

$K_{F P}$ : 流熱通過率 $\left[\mathrm{W} / \mathrm{m}^{\circ} \mathrm{C}\right]_{0} k_{R}$ : 集水時の流出係数 $[-](=0.85)_{0} K_{S}$ : 熱交換槽の熱損失係数 $\left[\mathrm{W} /{ }^{\circ} \mathrm{C}\right]\left(=14.7 \mathrm{~W} /{ }^{\circ} \mathrm{C}\right) 。 L_{F P}$ : 配管長 $\left[\mathrm{m}_{-}^{-} 。 N\right.$ : 壁面数 $[-]_{\circ} q$ : 冷水投入熱量 $[\mathrm{W}]_{\circ}$ $Q$ : 冷却塔使用水量 $\left[\mathrm{m}^{3} / \mathrm{s}\right]\left(=\mathcal{W}\left(x_{s}-x_{a}\right) / \gamma_{w}\right) 。 Q_{k}$ : 壁体内部質点 $k$ の熱容量 $\left[\mathrm{J} /{ }^{\circ} \mathrm{C}\right]_{\circ} Q_{O F}$ : 冷却塔からの飛散水量 $\left[\mathrm{m}^{3} / \mathrm{s}\right]\left(=0.4 \cdot \mathrm{V}_{\mathrm{CT}}{ }^{15}\right)$ 。 $Q_{r}$ : 室空気の熱容量 $\left[\mathrm{J} /{ }^{\circ} \mathrm{C}\right]_{\circ}$ $R_{c}$ : 雨水収集量 $\left[\mathrm{m}^{3} / \mathrm{s}\right]_{0} R_{i}$ : 壁内表面に吸収される短波放射量 $\left[\mathrm{W} / \mathrm{m}^{2}\right]_{0} r_{f}$ : 降水量 $\left[\mathrm{m}^{3} /\left(\mathrm{s} \cdot \mathrm{m}^{2}\right)\right]_{0} R_{o}$ : 壁外表面に吸収される短波放射量 $\left[\mathrm{W} / \mathrm{m}^{2}\right]_{0}$

$R_{O F}$ : 雨水のオーバーフロー量 $\left[\mathrm{m}^{3} / \mathrm{s}\right]_{\circ} S_{j}$ : 壁 $j$ の面積 $\left[\mathrm{m}^{2}\right]_{。} t$ : 時間 $[\mathrm{s}]_{C} V:$ 冷却塔内部の風量 $\left[\mathrm{m}^{3} / \mathrm{s}\right]_{\odot} V_{C T}$ : 冷却塔の循環流量 $\left[\mathrm{m}^{3} / \mathrm{s}\right]_{\circ} V_{T}$ : 熱交換槽有効容量 $\left[\mathrm{m}^{3}\right]_{0}$ 。 $V_{w}$ : 冷水流量 $\left[\mathrm{m}^{3} / \mathrm{s}\right]_{\circ} w$ : 冷水配管間隔 $[\mathrm{m}]_{0} x_{a}$ : 外気絶対湿度 $[\mathrm{kg} / \mathrm{kg}]_{0} x_{s}$ : 冷却塔から排出された空気の絶対湿度 $[\mathrm{kg} / \mathrm{kg}]_{\circ} \alpha_{i c}$ : 壁の対流熱伝達率 $\left[\mathrm{W} / \mathrm{m}^{2}{ }^{2} \mathrm{C}\right]_{\circ}$ $\alpha_{i r}$ : 壁の内表面放射熱伝達率 $\left[\mathrm{W} / \mathrm{m}^{2}{ }^{\circ} \mathrm{C}\right] 。 \alpha$ : 壁の外表面総合熱伝達率 $\left[\mathrm{W} / \mathrm{m}^{2}{ }^{\circ} \mathrm{C}\right]_{\circ} \eta_{F}^{*}$ : 配管径を考慮した冷水配管フィン効率 $[-]_{0} \eta_{F}$ : 冷水配管のフィン効率 $[-]_{0}$ $\theta_{a}$ : 外気温 $\left[{ }^{\circ} \mathrm{C}\right]_{c} \theta_{E}$ : 面 $k$ 周囲の等洒温度 $\left[{ }^{\circ} \mathrm{C}\right]_{0} \theta_{j}$ : 面 $j$ の内表面温度 $\left[{ }^{\circ} \mathrm{C}\right]_{\circ} \theta_{k}$ : 壁体内部質点 $k$ の温度 $\left[{ }^{\circ} \mathrm{C}\right]_{\circ} \theta_{k p}$ : 冷水配管表面温度 $\left[{ }^{\circ} \mathrm{C}\right]_{\circ} \theta_{r}$ : 室空気温 $\left[{ }^{\circ} \mathrm{C}\right]_{\circ}$ $\Delta \theta_{W}$ : 冷水の出入口温度差 $\left(=\theta_{W O}-\theta_{W I}\right)\left[{ }^{\circ} \mathrm{C}\right]_{。} \theta_{W W}$ : 冷水往きヘッダー入口水温 $\left[{ }^{\circ} \mathrm{C}\right]_{\circ} \theta_{W o}$ : 冷水還りヘッダー出口水温 $\left[{ }^{\circ} \mathrm{C}\right]_{\circ} \theta_{W k}$ : 冷却塔の出口温度 $\left[{ }^{\circ} \mathrm{C}\right] 。$ $\gamma$. 空気の密度 $\left[\mathrm{g} / \mathrm{m}^{3}\right]_{\circ} \gamma_{w}$ : 水の密度 $\left[\mathrm{g} / \mathrm{m}^{3}\right]_{0} \lambda$ : 泠却部材の熱伝導率 $\left[\mathrm{W} / \mathrm{m}^{2}{ }^{\circ} \mathrm{C}\right]_{\circ}$ 
体の断面構成を示す。表1に冷却塔放射冷房に関わる計算式 を示す。住宅のプランや断面構成、内部発熱・水蒸気発生の スケジュールは日本建築学会標準問題モデル11)を基準上し、 計算対象室は $1 \mathrm{~F}$ の居間、和室 (以下、 $\mathrm{LD}$ 室、CB室)とした。 ただし、空はプログラムの特性上面積を変えず1ヶ所にし た。また、躯体の断面構成は次世代省エネ基準IV地域相当の 断熱を満たすために、グラスウール24K相当の断熱材を外 壁に $90 \mathrm{~mm}$ 、床に $135 \mathrm{~mm}$ 、天井に90mm施すと仮定した ${ }^{17)}$ 。 表1の式(1)〜式(3) は室空気・壁体にお沙る熱収支式12)、 式(4)〜式(12)は放射冷却面における伝熱の計算式である 13)。また、式(13) は熱交換槽の熱収支式、式(14)、式(15) は雨水集水量 ${ }^{14)}$ 、冷却塔の水収支 ${ }^{14)}$ 15) である。なお、壁室 内側表面では、各壁間の相互放射を考慮し、Gebhartの放射 吸収係数を用いた計算を行った。各壁室内側表面の長波長 放射率は 0.9 とした ${ }^{122}$ 。

室空気や壁の温度変動の計算には後退差分法を用い、熱容量質点系 熱収支式を逆行列要素算出によって解いた ${ }^{12}$ 。計算時間間隔は $3600 \mathrm{~s}$ とした。冷却塔が日陰に設置されている場合、日射熱取得がないため、 周囲外気からの対流による熱取得上冷水から冷却水への除去熱量の和 が蒸発による潜熱放出上バランスし、冷却水温度が湿球温度程度にま で下げられると考える。そのため、熱交換槽へ送られる椧却水の温度 には外気温湿度における湿球温度を与えることにした。また、放射冷 却面内の熱伝導は冷水管のある面で一様に吸熱があると仮定した ${ }^{13)}$ 。 隣室の室空気温は計算対象室における前時刻の室空気温とした。

外気温湿度や日射量、降水量の入力データには拡張アメダス気象 デー夕標準年 (東京 大手町)のものを用い、冷房期間は外気温が $30^{\circ} \mathrm{C}$ 以上になる7月20日から9月10日とした。また、バッシブ手法のみ(以 下、パッシブ単独)の場合は、換気を終日 10 回/h(以下、換気 $24 \mathrm{~h}$ ) 行 い、熱交換パネルを設置しないこと以外は建築仕様が後述する表 30 仕様・運用条件と同様の室内熱環境々比較できるようにした。

後述する SET*の計算では注4)、代謝量を $67.6 \mathrm{~W} / \mathrm{m}^{2}$ (1.17met)、仕事 量を $0 \mathrm{~W} / \mathrm{m}^{2}$ 、着衣量を $0.6 \mathrm{clo}$ とした。なお、着衣量は長袖シャツを常
表2 数値シミュレーションの条件

\begin{tabular}{|c|c|c|}
\hline & パラメータ項目 & 条件 \\
\hline & 放射冷却面の位置 & 床·天井、床、天井、無 \\
\hline & \begin{tabular}{|l} 
蓄熱部位 \\
(位置、厚さ・材質)
\end{tabular} & 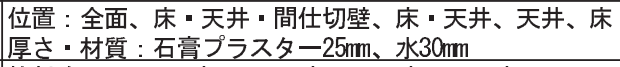 \\
\hline & 放射冷房と冷却塔の運転時間 & $\begin{aligned} \text { 放射冷房 : } 10 \text {-20時、12-18時、8-10時+11-19時、 } \\
\text { 8-13時+14-19時、11-14時+16-19時、 } \\
\text { 12-15時+16-19時、20-6時 } \\
\text { 冷却塔：放射冷房と同時運転、20-8時 } \\
\end{aligned}$ \\
\hline & 換気時間 $\cdot$ 換気回数 & $\begin{array}{l}\text { 換気時間 : 0時、16-8時 17-8時、18-8時、20-8時、24h } \\
\text { 換気回数 : } 0.5 \text { 回 } / \mathrm{h} 、 1 \text { 回 } / \mathrm{h} 、 1.5 \text { 回/h、2.0回/h、10回/h }\end{array}$ \\
\hline & 冷水配管の呼び径 ·間隔 & $\begin{array}{l}\text { 呼び径 :20A } 15 \mathrm{~A} 、 13 \mathrm{~A} 、 10 \mathrm{~A} 、 8 \mathrm{~A} 、 5 \mathrm{~A} \\
\text { 間隔: } 200 \mathrm{~mm}, 150 \mathrm{~mm} 、 130 \mathrm{~mm} 、 100 \mathrm{~mm} 、 80 \mathrm{~mm} 、 50 \mathrm{~mm}\end{array}$ \\
\hline & 計算対象室の方位 & 南東、西 \\
\hline & 雨水貯留タンク & $1250 \mathrm{~L} \sqrt{600 \mathrm{~L}}, 500 \mathrm{~L}$ \\
\hline 8 & 冷水流量 & $3 \mathrm{~L} / \mathrm{min}, 13 \mathrm{~L} / \mathrm{min}$ \\
\hline 9 & 日射遮蔽（簾） & 有り 無し \\
\hline & 室内風速 & $0.1,0.3 \mathrm{~m} / \mathrm{s}, 0.3 \mathrm{~m} / \mathrm{s}, 24 \mathrm{~h}, 0.3 \mathrm{~m} / \mathrm{s}, 0.7 \mathrm{~m} / \mathrm{s}$ \\
\hline
\end{tabular}

表3 実現性及び汎用性・コストを考慮した条件において

\begin{tabular}{|c|c|c|c|}
\hline パラメータ項目 & ハイスペック & 実用 $6 \mathrm{~h}$ & 実用 $10 \mathrm{~h}$ \\
\hline 放射冷却面の位置 & 床·天井 & & 床 \\
\hline $\begin{array}{l}\text { 蓄熱部位 } \\
\text { (位置、厚さ、材質) }\end{array}$ & $\begin{array}{l}\text { 壁面·天井: } \\
\text { 石膏プラスター } \\
25 \mathrm{~mm} \\
\text { 床:水蓄熱 } 30 \mathrm{~mm}\end{array}$ & $\mid \begin{array}{l}\text { 壁面·床· } \\
\text { 石站 } \\
25 \mathrm{~mm}\end{array}$ & $\begin{array}{l}\text { 天井: } \\
\text { 高プラスター }\end{array}$ \\
\hline 換気時間 & \multicolumn{3}{|c|}{ 16-8時 } \\
\hline \multirow{2}{*}{ 換気回数 } & \multicolumn{3}{|c|}{ 20-8時: 10回/h、8-16時:0.5回/h } \\
\hline & 16-18時:2回/h & $16-18$ & 時: 1.5 回 $/ \mathrm{h}$ \\
\hline 冷却塔放射冷房の運転時間 & 11-14+16-19時 & 12-18時 & 8-10+11-19時 \\
\hline
\end{tabular}

時着る人もいることから安全側を考慮して設定した。

2-3 数值シミュレーションのパラメータ

表 2 に数值シミュレーションの条件を示す。数值シミュレーション で用いたパラメータはパッシブ手法の中で比較的認知度の高いと思わ れる日射遮蔽や換気、蓄熱(冷)の3項目と運用条件に関わる放射冷却 面の位置、放射冷房や泠却塔の運転時間、冷水流量、冷水配管の呼び 径・間隔の5項目、その他に計算対象室の方位などを含む合計10項目 であり、これら全てのパターンについて検討を行った。

換気回数は、空を全開した場合で 10 回/h、空を完全に閉めた場合で 0.5 回/hとしたが、後述する結露回避のための換気の検討では、空を少し開

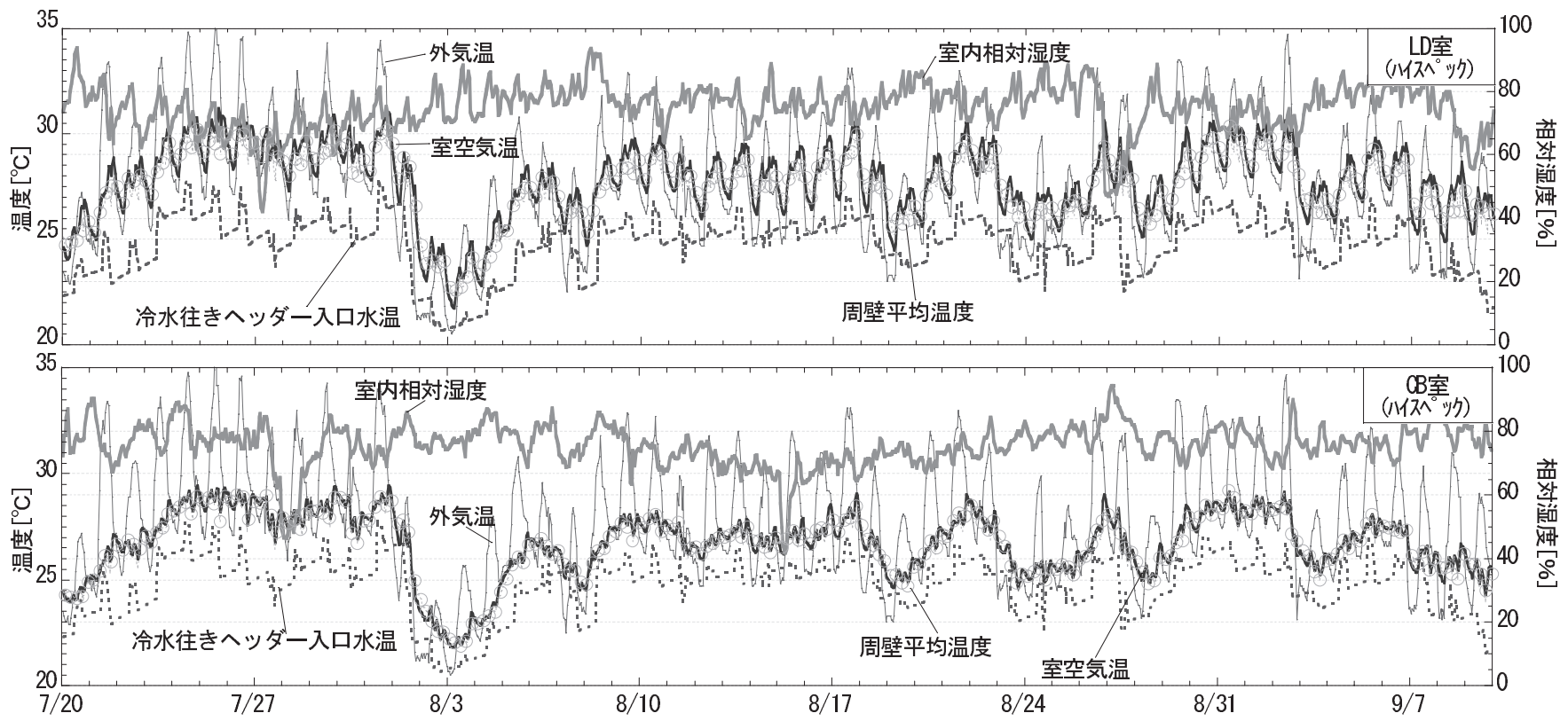

図 5 八イスペックの仕様・運用条件における $\mathrm{LD}$ 室・CB 室の室空気温・周壁平均温度・相対湿度 


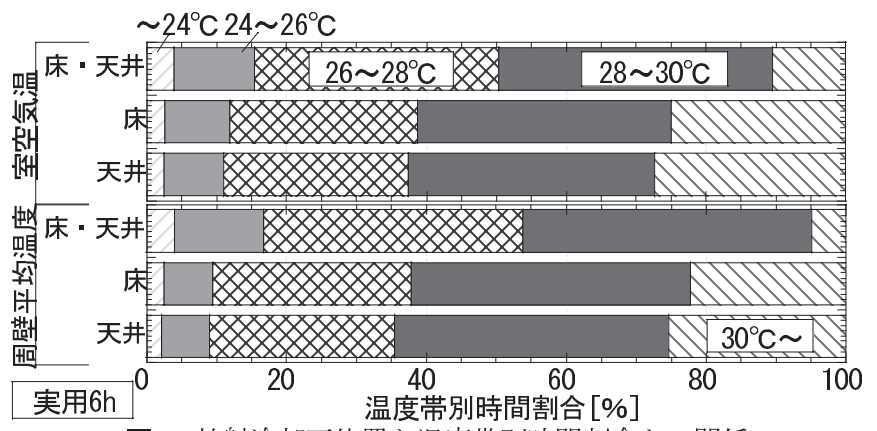

図6 放射冷却面位置と温度帯別時間割合との関係

$\sim 24^{\circ} \mathrm{C} \quad 24 \sim 26^{\circ} \mathrm{C}$

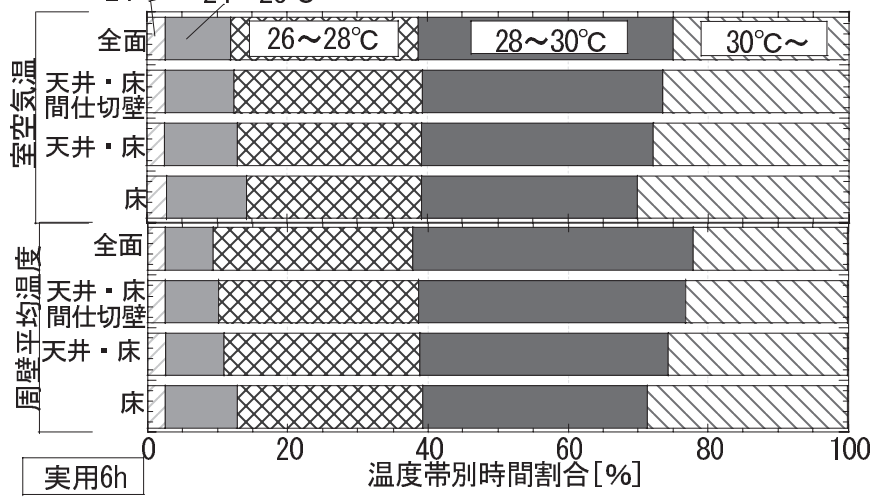

図7 蓄熱部位の位置と温度帯別時間割合との関係 $\sim 24^{\circ} \mathrm{C} 24 \sim 26^{\circ} \mathrm{C}$
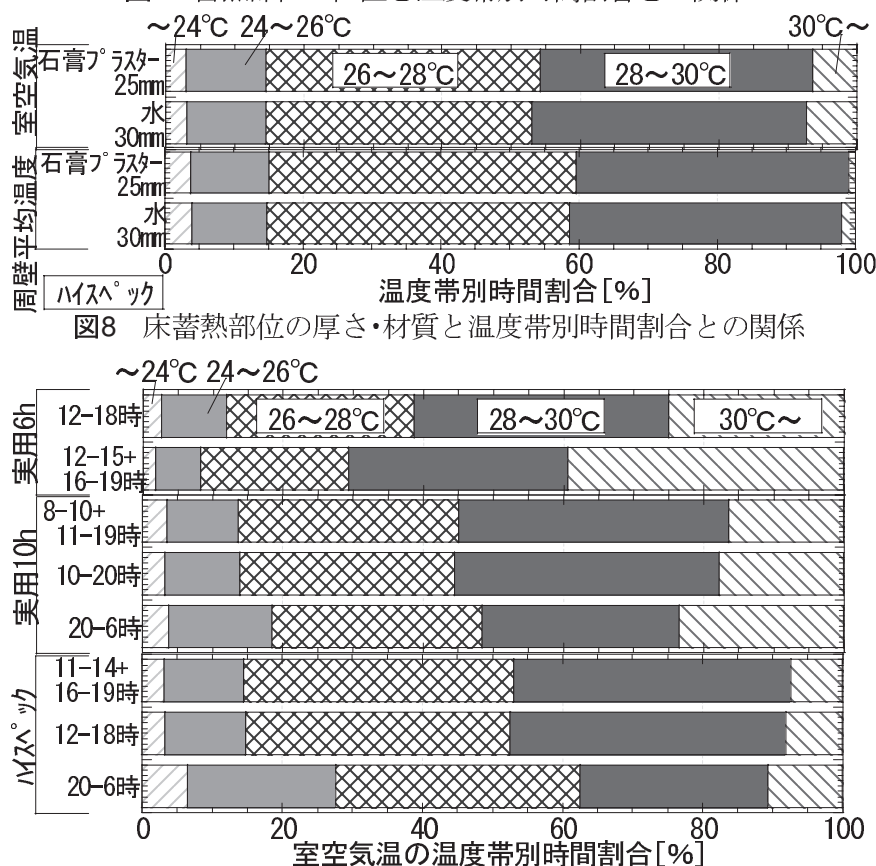

図9 放射冷房運転時間上室空気温の温度帯別時間割合との関係

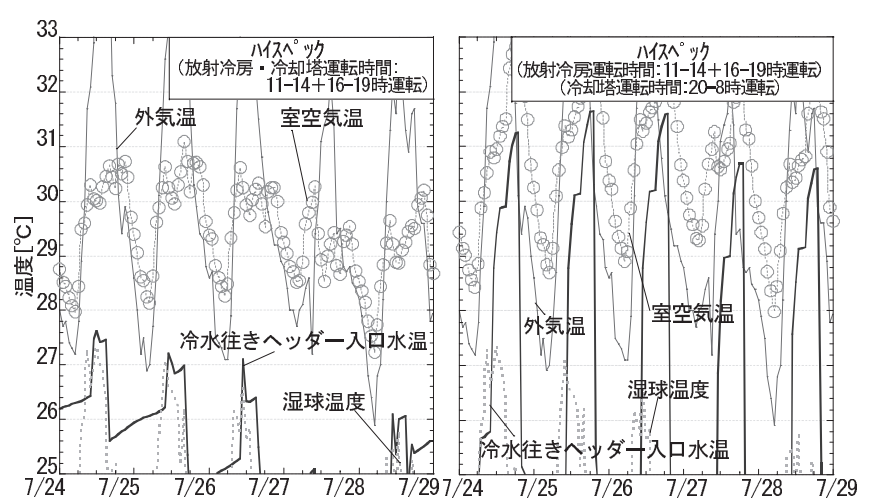

図10 冷却塔の運転時間上冷水往きヘッダー入口水温の変化
けた場合を想定して 1.5 回/h、または2回/hの換気回数を与えた。なお、 結露発生の条件上して、放射泠却面近傍が常時無風になっていると仮定 し、その温度が露点温度 (室中央の絶対湿度から算出) 以下になった場 合上した。放射冷房の運転時間は蓄熱効果による影響上夜間運転時にお ける結露発生のリスクを抑制するため、不在時も在室時に備えた予冷運 転を考慮して設定した。そのため、室内熱環境の評価は在室時だけでな く不在時も含めて行った。

結露を考慮し、内部発熱梳日本建築学会標準問題モデルの提案時より 電化製品の定格消費電力が小さくなっており、夏期は日の出が早いため、 現時点で一般的な機種と考えられるものを使用し、朝は照明を利用しな いと仮定して与えた(照明 $78 \%$ 減、機器 $40 \%$ 減)。日射遮蔽には室外日除

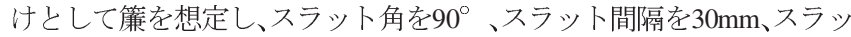
卜幅を $2 \mathrm{~mm}$ 、日射反射率を 0.1 と仮定した。

冷水管の呼び径仿、外径寸法が石膏ブラスター2枚の厚さを超えないこ とから20A以下に、間隔は曲げ部分の配管断面が歪まないようにするた めに呼び径寸法の10倍で一般に施工されることから設定した。

\section{3. 結果·考察}

表3に実現性及び汎用性・コストを考慮した条件において室空気温 が最低になった各仕様・運用条件を示す。本論文では、室空気温が30 ${ }^{\circ} \mathrm{C}$ 未満になることを目指しているが、利用者により許容範囲が異なる ため、 $30^{\circ} \mathrm{C}$ 未満になる時間割合が9割以上の「ハイスペック」、8割以 上の「実用 $10 \mathrm{~h} 」 、 7$ 割以上の「実用 $6 \mathrm{~h} 」$ といら仕様を設けた。なお、八 イスペックは施工性を考慮して放射冷却面を2面とし、実用は汎用性 を考慮して放射冷却面を1面とした。

パラメータ項目とその条件の数が多いため、以下の結果・考察では、 数值シミュレーションにより試行錯誤して求めた最低室空気温の条件 の結果(表3の条件)を使い、1つのパラメータ条件のみを変えて説明す る。

図5に冷房能力が最も高いハイスペックの仕様・運用条件における LD室、 $\mathrm{CB}$ 室の室空気温・周壁平均温度などの経時変化を示す。室空 気温の期間最高值は LD室で 7 月 25 日 16 時に $31.2^{\circ} \mathrm{C} 、 \mathrm{CB}$ 室で 7 月 24 日 22 時に $29.5^{\circ} \mathrm{C}$ なった。また、周壁平均温度の期間最高值はLD室 で7月 31 日 21 時に $30.4^{\circ} \mathrm{C} 、 \mathrm{CB}$ 室で7月 25 日 15 時に $29.3^{\circ} \mathrm{C}$ にった。 3-1 仕様·運用条件と冷房効果の関係

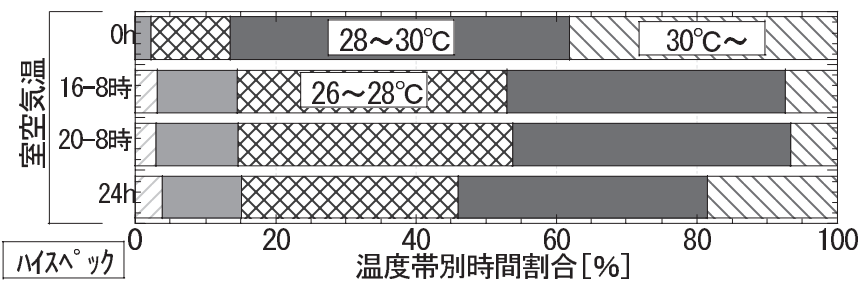

図11 換気時間帯と室空気温の温度帯別時間割合との関係 $(2$ 回 $/ \mathrm{h})$

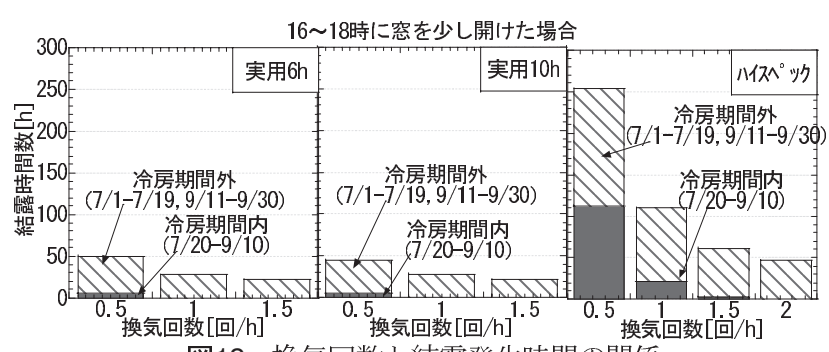

図12 換気回数と結露発生時間の関係 


\section{3-1-1＼cjkstart放射冷却面の位置と冷房効果の関係}

図6に実用6hにお汸放射冷却面位置と温度帯別時間割合上の関係 を示す。室空気温が $28^{\circ} \mathrm{C}$ 以上になる時間割合は、放射冷却面を床・天 井にした場合で $50 \%$ 、床のみで $61 \%$ 、天井のみで $63 \%$ となり、同程度 だった。周壁平均温度も室空気温とほぼ同様の結果になった。

また、放射冷却面の面積を大きくした場合、漏水の可能性やコスト の増加なら゙が考えられる。そのため、前述表 3 のように、実用は放射

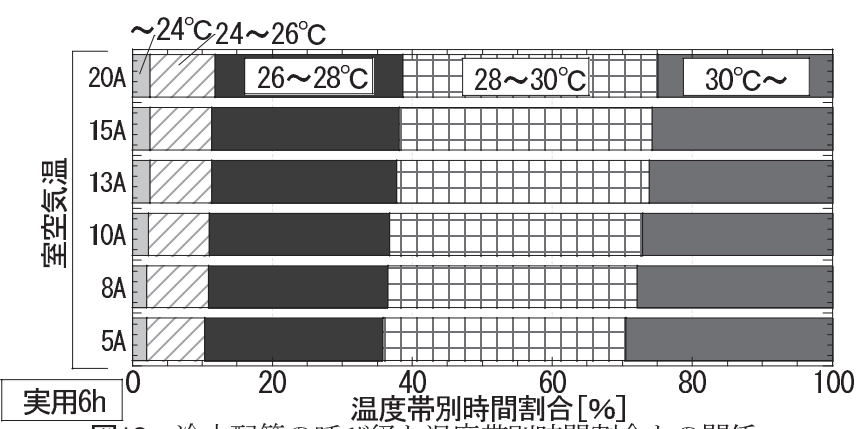

図13 冷水配管の呼び径亡温度帯別時間割合との関係 $\sim 24^{\circ} \mathrm{C} 24 \sim 26^{\circ} \mathrm{C}$

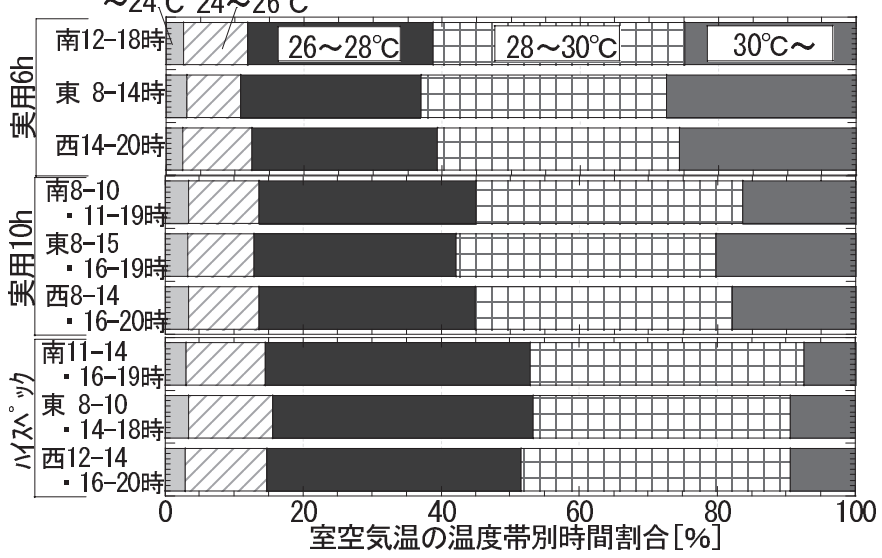

図14 室方位・放射冷房運転時間と温度帯別時間割合との関係

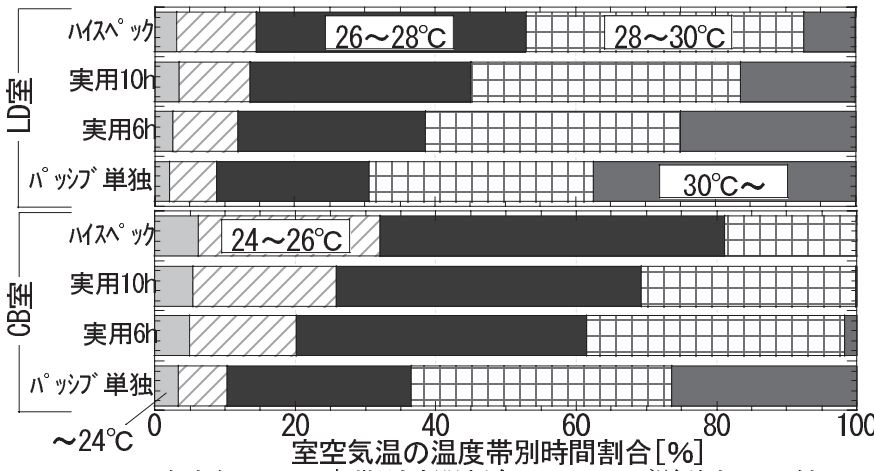

図15＼cjkstart室空気温の温度帯別時間割合のパッシブ単独との比較

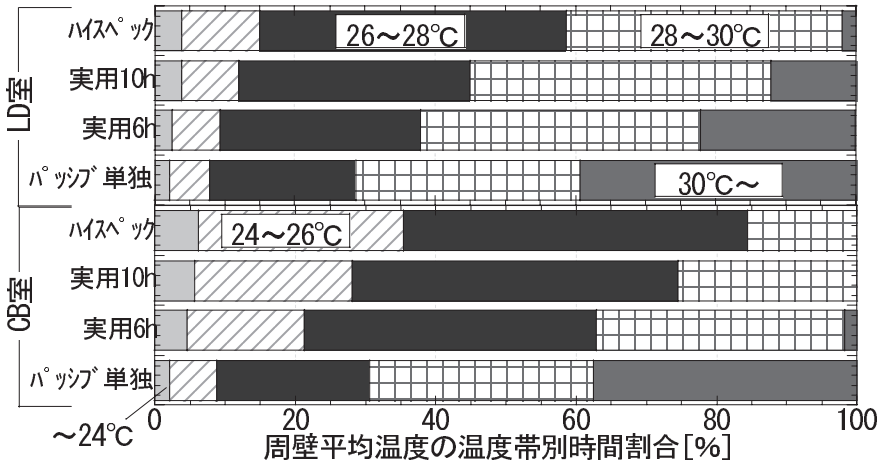

図16 周壁平均温度の温度帯別時間割合のパッシブ単独との比較
冷却面を床のみに設け、ハイスペックは放射冷却面を床・天井に設け ることが妥当と判断した。

\section{3-1-2＼cjkstart蓄熱部位の位置·材質·厚さと冷房効果}

図7に実用6hにおける蓄熱部位の位置と温度帯別時間割合との関 係、図8にハイスペックに㧍ける床蓄熱部位の厚さ・材質と温度帯別 時間割合との関係を示す。室空気温、周壁平均温度が $28^{\circ} \mathrm{C}$ 以上になる 時間割合は、蓄熱部位の位置に関係なく約 $60 \%$ である。しかしながら、 $30^{\circ} \mathrm{C}$ 以上になる時間割合は、室空気温、周壁平均温度ともに蓄熱部位 が周壁全面の場合で $22 \%$ と最も小さく、床の夕に蓄熱部位を設けた場 合が $29 \%$ で最も大きい。実用では、冷媒温度が比較的高くなるため、 蓄冷効果が減少し、蓄熱部位の材質上厚さを石膏プラスター $25 \mathrm{~mm}$ 上 水 $30 \mathrm{~mm}$ (保冷剤用の厚さ $30 \mathrm{~mm}$ のプラスチック容器に水を注入したも の。以下、水カプセル)にした場合上差異があまり見られなかった。蓄 冷(熱)効果の高いハイスペックでは、放射冷房の運転時間数により蓄 冷効果が大きくなるため、蓄熱部位を水カプセル $30 \mathrm{~mm}$ とし、実用は 安価で施工性の高い石膏プラスター $25 \mathrm{~mm}$ が妥当と考える。

\section{3-1-3 放射冷房·冷却塔の運転時間と冷房効果の関係}

図9に放射冷房運転時間と室空気温との温度帯別時間割合の関係、 図10にハイスペックにおける冷却塔の運転時間上冷水往きヘッダー入 口水温の変化を示す。放射冷房の運転時間が最も短く、室空気温を低 く抑えることができたのは、実用 6h で 12-18 時、実用 $10 \mathrm{~h}$ で 8-10 時 及び11-19時 (以下、8-10時+11-19時)、八イスペックで11-14時+1619 時となった。室空気温が $28^{\circ} \mathrm{C}$ 以上になる時間割合は、実用 $6 \mathrm{~h} の$ 場 合、12-15 時+16-19時運転のように放射冷房の運転を2回に分けるこ とによって9ポイント大きくなる。実用 $10 \mathrm{~h}$ とハイスペックの場合、放 射冷房の運転時間を 2 回に分けることにより、室空気温が $30^{\circ} \mathrm{C}$ 以上に なる時間割合は 1 ポイント小さくなる。

当日 20 時〜翌日 6 時 (以下、20-6時) の運転では、 $28^{\circ} \mathrm{C}$ 以下になる室 空気温・周壁平均温度の時間割合は他の運転時間帯より大きくなって いるが、これは夜間であり、日中は逆に仕様に関係なく $30^{\circ} \mathrm{C}$ 以上にな る時間割合は他の運転時間帯の場合より、3ポイント以上大きくなる。 冷却塔と放射冷房の運転時間を同時刻にした場合 (表3の条件) 上、 冷却塔を夜間に運転した場合と比べると、冷水往きヘッダー入口水温 差は8月 1 日 18 時に最も差が大きくなり、冷却塔上放射冷房を同時刻 に運転した場合の方が $8.3^{\circ} \mathrm{C}$ 低くなった。このとから、冷却塔と放射 冷房の同時運転が妥当と考える。

\section{3-1-4＼cjkstart結露回避のための換気条件}

図11にハイスペックを対象とした換気時間帯と室空気温との温度帯 別時間割合の関係、図12に16-18時の換気における換気回数上結露発 生時間の関係を示寸。周壁平均温度の温度帯別時間割合は図11 と同様 になった。室空気温が $28^{\circ} \mathrm{C}$ 以上になる時間割合は、20-8時の換気が54 \%で最も大きくできるが、7/23〜8/1以外は概ね17 時前後に結露が発 生した。そこで、換気回数は 16-18 時に実用で 1.5 回/h、ハイスペッ クで 2.0 回 $/ \mathrm{h} 、 18-8$ 時の換気は全て 10 回 $/ \mathrm{h}$ と寸れば、結露の発生を 回避し、20-8時に換気した場合と室空気温の変動が同様になる。

\section{3-1-5＼cjkstart冷水配管の径·間隔と冷房効果の関係}

図13に実用6hを対象とした冷水配管の呼び径と温度帯別時間割合 との関係を示す。呼び径 $5 \mathrm{~A}$ の場合、 $28^{\circ} \mathrm{C}$ 以上の時間割合は、室空気温 で64\%、周壁平均温度で67\%である。これは20Aの場合よりそれぞれ 3ポイント、5ポイント大きい。また、呼び径と配管間隔で比較した場 


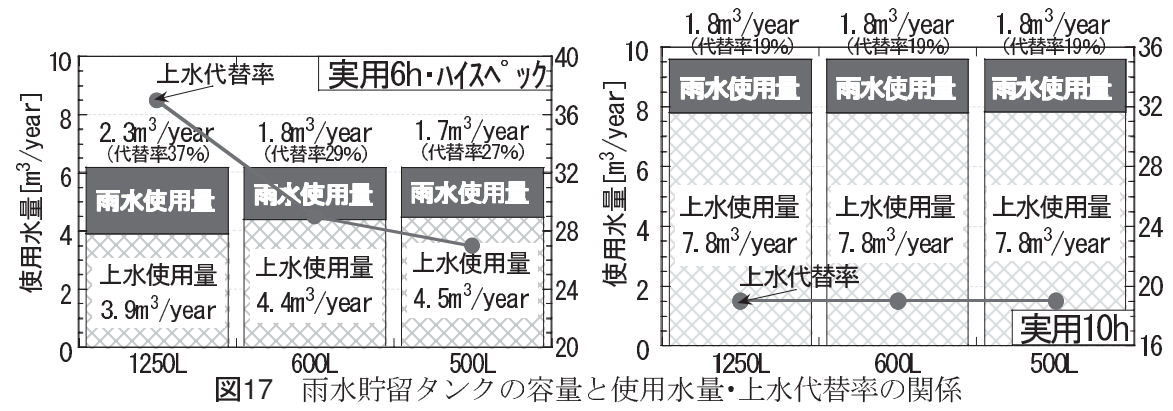

水量自体が大きいために貯留した雨水が速やか に使いきられ、上水が大量に補給されることに より、雨水貯留タンクの容量が異なっても雨水 使用量に差が生じなくなっていると考える。

\section{4. 結論}

策による室外日除けと次世代省エネルギー基 準相当の断熱を施した東京の戸建住宅を対象 に、冷却塔放射冷房の仕様・運転方法に関寸る

合、呼び径が小さくなるほど、温度が低い場合の時間割合が小さく なっている。配管間隔を小さくする場合、配管長が大きくなり、その 圧力損失が大きくなるため、ポンプの使用電力が大きくなる。これら のことから、冷水配管は、施工が容易な、呼び径が $20 \mathrm{~A} 、$ 間隔が $200 \mathrm{~mm}$ のもの(以下、20A・200mm)が望ましいと考える。

\section{3-1-6 室方位と冷房効果の関係}

図14に計算対象室方位・放射冷房運転時間と温度帯別時間割合との 関係を示す。南に面する室では、実用6hが 12-18 時、実用 $10 \mathrm{~h}$ が 8-10 時+11-19時、ハイスペックが11-14時+16-19時、東に面する室では実 用 6h が 8-14 時、実用 $10 \mathrm{~h}$ が 8-15 時+16-19 時、ハイスペックが 8-10 時+14-18時の場合に室空気温が最低に抑えられた。西に面寸る室では 実用 6hが 14-20 時、実用 10hが 8-14時+16-20 時、ハイスペックが 1214時+16-20時の場合に、室空気温が最低になった。このことから、南 に面する室では12-14時+16-18 時、東に面する室では8-10 時、西に 面する室では16-20時に冷却塔放射冷房を連続運転し、外気温の高い 時間だけでなく日射の影響が生じる前から室内を冷却することが冷房 には効果的である。

\section{3-2 パッシブクーリングの補完効果と水使用量}

\section{3-2-1パッシブクーリングの補完効果}

図15、図16に室空気温・周壁平均温度の温度帯別時間割合にお打る パッシブ単独との比較を示す。CB 室で室空気温、周壁平均温度が 28 ${ }^{\circ} \mathrm{C}$ 以上になる時間割合は、それぞれパッシブ単独で $60 \%$ 、64\%、実用 6h で39\%、37\%、実用 $10 \mathrm{~h}$ で $31 \%$ 、25\%、ハイスペックで 19\%、16 \%である。内部発熱が大きく、部屋が広いLD室では、室空気温、周壁 平均温度が $28^{\circ} \mathrm{C}$ 以上になる時間割合はパッシブ単独でそれぞれ $69 \%$ 、 $71 \%$ 、実用 $6 \mathrm{~h}$ で $61 \%$ 、62\%、実用 $10 \mathrm{~h}$ で $55 \%$ 、55\%、ハイスペック で $47 \% 、 41 \%$ となった。冷却塔放射冷房を導入することにより、CB室 では室空気温や周壁平均温度が $28^{\circ} \mathrm{C}$ 以上になる時間割合を $21 \sim 48$ ポ イント、 $\mathrm{LD}$ 室では温度が $28^{\circ} \mathrm{C}$ 以上になる時間割合を 7 ～ 30 ポイント 減らすことができる。

\section{3-2-1 水使用量·上水代替率}

図17に雨水貯留タンクの容量上使用水量・上水代替率の関係を示 す。上水代替率 (雨水使用率) は、実用 $6 \mathrm{~h} の$ 場合、雨水貯留タンクの容 量1250L で37\%、600L で29\%、500L で27\%になった。実用10h の場 合、上水代替率は雨水貯留タンクの容量に関わらず $19 \%$ である。八イ スペックでは、上水代替率が雨水貯留タンクの容量 $1250 \mathrm{~L} て ゙ 39 \% 、 600 \mathrm{~L}$ で31\%、500Lで29\%である。冷却塔放射冷房では、蒸発などにより 冷却塔から外部へ排出される水量の值が使用水量となる。そのため、 放射冷房の運転時間数と運転時間帯によって上水代替率に差が生じた と考える。また、使用水量の大きい実用 $10 \mathrm{~h}$ 以外梳、雨水貯留タンク

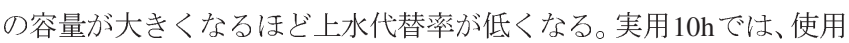

数值シミュレーションを行った結果、以下のことが明らかになった。

1) 放射冷却面を床上天井に設置すると、床や天井の久設置の場合上 り室空気温や周壁平均温度が $28^{\circ} \mathrm{C}$ 以上になる時間割合が 11 ポイ ント以上減少し、61\%になる。壁に配管を埋設すると家具のレイ アウトが問題になるため、放射冷却面は床と天井、または床のみ に導入することが望ましい。

2) 蓄熱部材が石膏プラスター $25 \mathrm{~mm}$ と水入りカプセル $30 \mathrm{~mm}$ の場合 では、熱容量に差があるにもかかわらず、それらを床に導入して 比較した結果、室空気温・周壁平均温度にほとんど温度差が見ら れない。蓄熱部位を周壁全面にした場合、室空気温が $30^{\circ} \mathrm{C}$ 以上に なる時間割合は、25\%に抑えることができる。

3) 冷房期間 (7月 20日〜9月 10日)放射冷却面 1面の場合では 16:00 〜 18:00の換気回数を 1.5 回/hとし、放射冷却面 2 面の場合では 2.0 回 $/ \mathrm{h}$ 上し、当日 18:00〜翌日 8:00に10回 $/ \mathrm{h}$ で換気すると、放 射冷房時の壁面結露を回避できる。

4）南に面する室では 12:00～14:00及び16:00〜 18:00、東に面する 室では8:00〜 10:00、西に面する室では 16:00～20:00に冷却塔 放射冷房運転することで、室方位や運転時間数、仕様に関わらず 室空気温のピークを低く抑えることができる。

5) $\mathrm{CB}$ 室で室空気温、周壁平均温度が $28^{\circ} \mathrm{C}$ 以上になる時間割合は冷 却塔放射冷房を導入することで、パッシブ手法のみより $21 〜 48$ ポイント減り、16〜39\%になる。また、LD室で室空気温、周壁 平均温度が $30^{\circ} \mathrm{C}$ 以上になる時間割合は、冷却塔放射冷房を導入す ることで、パッシブ手法のみより 7 ～30ポイント減り、41〜 62 \%になる。

本研究では、東京にお沙る冷却塔放射冷房の仕様・運転方法などを 明らかにしたが、今後は地域別に本システムの冷房効果を検討寸る必 要があると考える。

\section{謝辞}

本研究における冷却塔放射冷房の設計では、(有)ZO設計室の伊藤教 子さん・布施安隆さんに貴重なご協力をいただきました。また、数值 シミュレーションでは、当時東海大学大学院生の辻康昭さんに貴重な ご協力を賜りました。ここに記して謝意を表します。

なお、本研究は平成 22 年度文部科学省科学研究補助金 (基盤研究 (B)、課題 :「人一自然共生建築」系のエクセルギー消費最適化に関す る研究、研究代表者: 宿谷昌則、研究分担者: 斉藤雅也・高橋達)の 補助により実現しました。

注

注 1) 図A.1のように放射冷暖房の冷却源に冷却塔を用いることで夏期は放射 


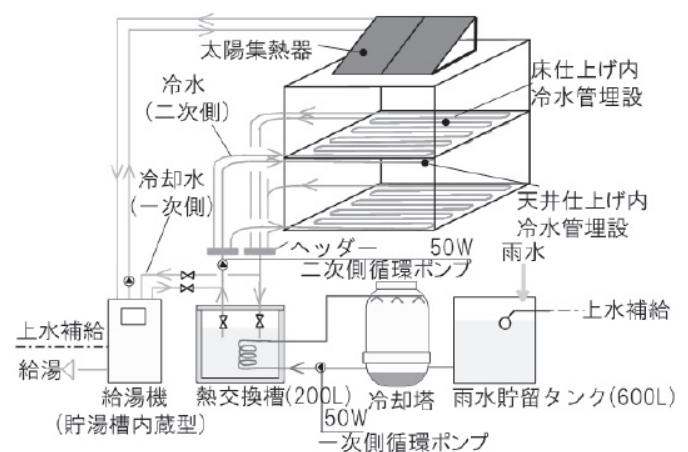

図A.1 冷却塔放射冷房及び放射暖房のシステム

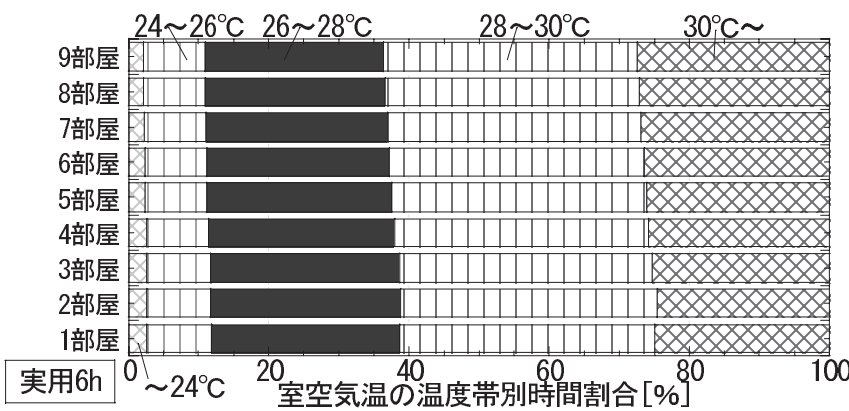

図A.2 部屋数別における室空気温之の温度帯別時間割合

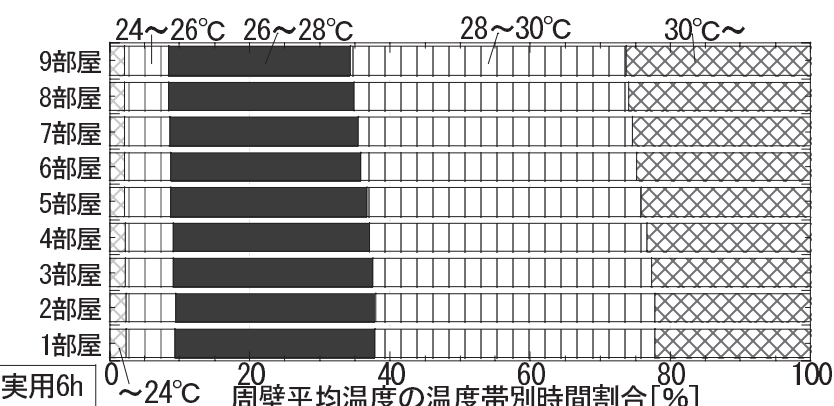

図A.3 部屋数別における周壁平均温度との温度帯別時間割合 $\sim 24^{\circ} \mathrm{C} 24 \sim 26^{\circ} \mathrm{C}$

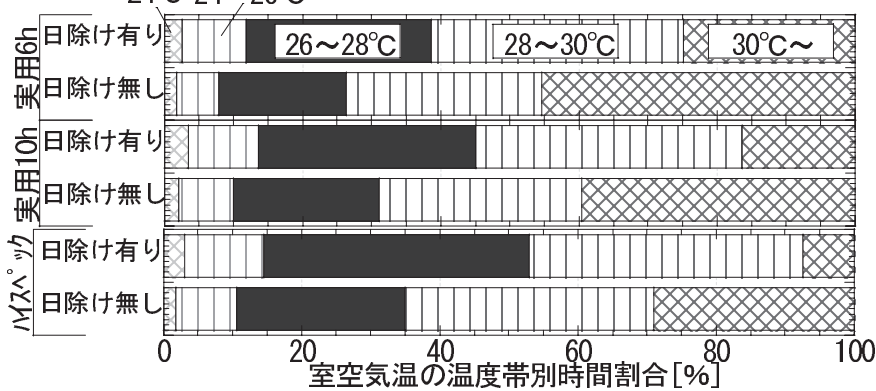

図A.4 日除けの有無と室空気温の温度帯別時間割合との関係

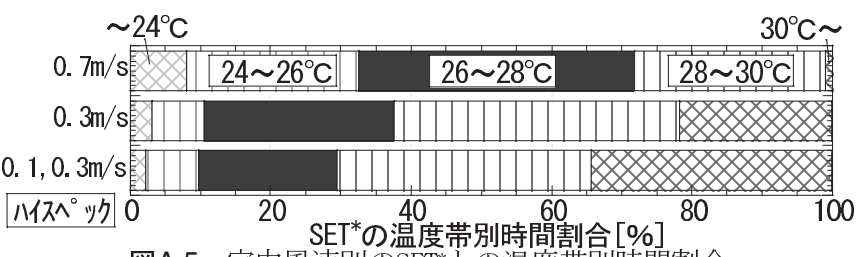

図A.5 室内風速別のSET主の温度帯別時間割合

冷房を行い、冬期は太陽集熱器と給湯器を加熱源に用いることで同一の 冷水配管を利用して放射暖房を行うことができる5)。

注 2) 放射冷房時における結露回避のために温度制御の機構を導入すると、そ のイニシャルコストがエアコン費用以上に相当し、普及性が低くなるた め、イニシャルコストが数万円で済む漏水センサーにより冷水配管 (金属 バルブなど)で結露を検知し、そのアラーム表示やブザ一音をもとに手動 でバルブを閉じる方法が有効と考えている。

注 3) 1.3 で述べた以外に、実用 $6 \mathrm{~h}$ 老対象に $\mathrm{LD}$ 室の部屋数を 1 室〜 9 室まで
増やした場合のシミュレーションを行った結果、図A.2の上うに水温は 部屋数と比例して上昇していた。しかしながら、図A.3、図A.4のように 室空気温と周壁平均温度が $30^{\circ} \mathrm{C}$ 以上になる時間割合は、それぞれ $2 \% 、 4$ \%に留まる。このように市販の最小能力の冷却塔を用いた場合、最大 8 部屋の冷房が可能となるので、戸建住宅には過大能力である。図 A.5 の ように日射遮蔽の有無によって室空気温が $30^{\circ} \mathrm{C}$ 以上になる時間割合の差 は22 ポイント前後に留まる。図A.6のように扇風機や天井扇などを用い て室内風速を $0.7 \mathrm{~m} / \mathrm{s}$ にした場合は、自然換気を行った場合より $\mathrm{SET}^{*}$ が $30^{\circ} \mathrm{C}$ 以上になる時間割合は $33 \%$ 小さくなる。

注 4) 北川・田辺らは、放射冷房を行っている人工気候室で同一のSET*゙あっ ても、無風時と風速 $0.1 \sim 0.3 \mathrm{~m} / \mathrm{s}$ とでは温冷感申告がそのスケールで士

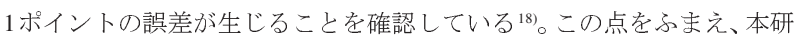
究では室内熱環境の快適性をSET*などで評価はせずに、熱環境要素の集 約的物理量として示寸に留めた。

注 5) 冷房機関全体ではなく、在室時のみに着目すると、室空気温が $28^{\circ} \mathrm{C}$ 以上 になる時間割合は、LD室の場合、ハイスペックで $34 \%$ 、実用 $6 \mathrm{~h} て ゙ 45 \%$ 、 実用 $10 \mathrm{~h}$ で $40 \%$ 、CB 室の場合、ハイスペックで $13 \%$ 、実用 $6 \mathrm{~h}$ で $22 \%$ 、 実用 $10 \mathrm{~h}$ で $19 \%$ である。また、 $28^{\circ} \mathrm{C}$ 以上になる周壁平均温度の時間割合 は、LD室の場合、ハイスペックで $25 \%$ 、実用 $6 \mathrm{~h}$ で $41 \%$ 、実用 $10 \mathrm{~h}$ で 36 $\%$ 、CB 室の場合、ハイスペックで $10 \%$ 、実用 $6 \mathrm{~h}$ で $22 \%$ 、実用 $10 \mathrm{~h}$ で 19 \%だった。

注 6) 冷却塔メーカーは、自動薬剤注入装置をコスト・スペースの問題から導 入できない場合のために、薬剤ホルダーをオプションとして販売してい る。また、一回冷却塔内に吊るすことにより、3 月月殺菌能力をもつ塩素 系抗レジオネラ薬剤が複数市販されている ${ }^{19}$ 。これらのことから住宅に おいてローコストでの衛生管理は可能と考える。

注 7) 熱交換槽にお汁る冷却水の出入口温度差を $2.5^{\circ} \mathrm{C}$ とた場合、その除去熱 量は 4550Wになる。熱交換器の流速が $1.5 \mathrm{~m} / \mathrm{s}$ であることから、熱交換器 の管内強制対流熱伝達率は $4710 \mathrm{~W} /\left(\mathrm{m}^{2} \cdot \mathrm{K}\right)^{20)}$ 、管外の水中の自然対流時に おける対流熱伝達率の上限が $580 \mathrm{~W} /\left(\mathrm{m}^{2} \cdot \mathrm{K}\right)^{21)}$ 、銅管の熱伝導率は $515 \mathrm{~W} /$ $\left(\mathrm{m}^{2} \cdot \mathrm{K}\right)$ となる。そのため、4550W の交換熱量を有する熱交換器には $3.58 \mathrm{~m}^{2}$ 以上の表面積が必要になることから、 $3.58 \mathrm{~m}^{2}$ 強の伝熱面積をもつ $20 \mathrm{~A}$ 銅管を直径 $500 \mathrm{~mm}$ で 18 段巻いた熱交換器とした。温度効率 1.0 に相 当する最大熱交換量を与えるような熱交換器を想定したため、式 13) 右 辺には温度効率の記号を乗じていない。

\section{参考文献}

1）石原衣梨・高橋達: 戸建住宅における冷却塔放射冷房によるパッシブ手法 の補完に関寸る研究, 日本建築学会大会学術講演梗概集, D-2, pp.555556,2012

2) 高橋達・辻康昭・伊藤教子: 井水放射冷却・外気予泠兼用システムの開発 と室内熱環境調整に関する実測調査, 日本建築学会環境系論文集, 第76 巻, 第 670 号, pp.1043-1050, 2011-12

3) 五十嵐賢征・水澤崇則・高橋達・黒岩哲彦: 室内気流を促進させた二重屋 根採冷システムにおける快適性の研究 その2. 温冷感・快適感の申告と 室内熱環境, 日本建築学会大会学術講演梗概集, D-2, pp.557-558, 2007-8

4) 高橋達・黒岩哲彦:雨水の蒸発を利用した二重屋根採冷システムの開発上 室内熱環境の実測, 日本建築学会環境系論文集, 第 573 巻, pp.55-61, 2003-11

5) 高橋達・伊藤教子: 雨水放射冷房システムの取り組み一冷却塔利用放射冷 房によるパッシブ手法の補完, 日本建築学会 環境工学委員会 熱環境運 営委員会 第41 回熱シンポジウム, pp.57-62, 2011.10

6) 馬景輝・須永修通: 屋根流水を用いた天井放射冷房の熱性能に関寸る実験 研究 屋根流水冷房システムに関する研究その1, 日本建築学会環境系論 文集，第596 号，pp.29-35，2005

7）馬景輝・須永修通: 屋根流水放射冷房システムに関する研究 その 4 . シス テムの有効性と被験者による快適性の評価, 日本建築学会大会学術講演 梗概集，D-2, pp.653-654, 2005-9

8）深井友樹 - 三戸部元洋 - 井澤健輔 - 淺田秀男 - 岩松俊哉 - 福田秀朗 - 大 熊武・宿谷昌則: 高温放射冷房と低温放射暖房における快適性に関寸る実 験研究 その 2, 日本建築学会大会学術講演梗概集, D-2, pp.583-584, 2007-8

9）榊原秀幸・荒谷登・石田秀樹: 冷却塔の直接利用による天井バネル式冷房 の可能性の検討, 日本建築学会大会学術講演梗概集, D-2, pp.931-932, 1985

10) P. Vangtook and S. Chirarattananon:Application of Radiant Cooling as A 
Passive Cooling in Hot and Humid Climate, Building and Environment, No. 42, pp.543-556, 2007

11) 宇田川光弘: 標準問題の提案, 日本建築学会環境工学委員会, 熱分科会第 15 回熱シンポジウム, pp.23-33, 1985

12) 宿谷昌則: 数值解析で学ぶ光と熱の建築環境学, 丸善, pp.94-99,pp.161207, 1993

13) 平田勝彦・宿谷昌則: 蓄熱式床暖房システムの数值解析一床の蓄熱性, 建 物断熱性, 室内熱環境、温水投入熱量の関係に関寸るケーススタディ, 日本建築学会計画論文報告集, 第419号, pp.39-46, 1991.1

14）（財） 空気調和・衛生工学会: 雨水利用システム設計と実務, 丸善株, pp.50-55, 1997

15）高砂熱学工業株総合研究所：ビル用マルチ泠媒サブクールシステムの排熱 量と運転経費のモデル計算，大阪府環境情報センター, pp.2-4, 2006

16) 国土技術政策総合研究所・建築研究所 監修: 自立循環型住宅八の設計ガ イドライン, (財) 建築環境・省エネルギ一機構, pp.39-46, 2006

17) 柿沼整三:建築断熱の考え方，才一ム社，pp.149-154，2004

18）北川晃一・早野ひろ子・斎藤俊彦・菰田紀子・田辺新一: 放射冷房時にお ける気流上温度の体感への影響, 人間と生活 環境, 4 (1), pp.42-51, 1996

19) http://www.legikyo.gr.jp/index.html : (抗レジオネラ用空調水処理剤協議 会 Web サイト) , 2012.9.29

20) http://engineering-web.com/heat_ja/pipeDittus : (円管内強制対流・熱伝達 率・Dittus-Boelterの式 Web サイト) , 2012.9.29

21) http://www.solmind.com/sofuto/dennnetu/enntou.htm : (伝達計算 Web サイ ト) , 2012.9.29

(2012年 6 月 2 日原稿受理，2012年10月26日採用決定） 